\title{
Breast Cancer Type 2 Susceptibility Protein
}

National Cancer Institute

\section{Source}

National Cancer Institute. Breast Cancer Type 2 Susceptibility Protein. NCI Thesaurus.

Code C17916.

Breast cancer type 2 susceptibility protein (3418 aa, $\sim 384 \mathrm{kDa}$ ) is encoded by the human BRCA2 gene. This protein plays a role in both cell cycle regulation and DNA repair. 